\title{
AN EPITOMF OF BACTERIAL DISEASES OF PLANTS IN GREAT BRITAIN AND IRELAND.
}

\author{
BY SYDNEY G. PAINE. \\ (Lecturer in Plant Bacteriology in the Department of Plant Physiology \\ and Pathology, Imperial College of Science and Technology, London.)
}

THE study of bacteria in relation to plant diseases is a branch of plant pathology which has been largely neglected in this country. In fact it is unfortunate that plant pathology as a whole has not received the amount of attention at the hands of English botanists that its importance in agriculture and horticulture demands. Bacteriology in particular has suffered from neglect to such an extent that the knowledge of bacterial diseases of plants occurring in this country is limited to a very few diseases only. It would indeed be fortunate if this were due to the nonexistence of others, but there is no reason to believe that the activities of bacterial parasites are less here than they are in other countries with a temperate climate. The unsatisfactory state of affairs was deplored by Prof. Potter in 1910(35) and since that time very little has been done to improve the position. The question calls for the urgent attention of botanists in order that this, which can only be described as a national disgrace, may be immediately remedied. Until quite recently no one in this country has applied himself solely to the study of bacterial diseases.

The leaflets of the Board of Agriculture include only six diseases attributed to bacteria(25) whereas in a general conspectus of bacterial diseases E. F. Smith(45) has compiled a list of 140 genera distributed through more than fifty families in which such diseases are known to occur.

Our present knowledge of bacterial diseases is mainly due to the American plant pathologists and the main reason why we in this country are so far behind the Americans in this respect is that we have no stateaided department of plant pathology which is in the least comparable with that of the American Bureau of Plant Industry. Other reasons are to be found in the facts that plant pathology and plant bacteriology in particular as a general rule form either no part or only a very subsidiary part of the curriculum of the botany student and that where such training is included in his curriculum the student is more attracted by the 
mycological than by the bacteriological side of plant pathology. The investigation of bacterial parasitism in plants above all things demands of the plant pathologist an extremity of patience with which few perhaps are gifted. The difficulties met with in the isolation of the parasite from diseased plant tissues are infinitely greater than those encountered in the isolation of an animal parasite. The animal pathologist has in the blood a very specialised medium which excludes almost entirely the invasion of saprophytic forms; on the contrary, the sap of the plant cells is eminently suitable as a medium for the growth of many common bacteria, and, situated as the plant is in a soil containing upwards of five million organisms per gram, when once its defence against parasitism has been broken down by the entry of a parasite, many of these common soil organisms enter the diseased tissue and multiply luxuriantly often to the partial, and sometimes even to the total, exclusion of the original parasite. In attempts to isolate the parasite from potato stems affected with "Blackleg" the author spent several months battling with a multitude of saprophytes before success attended his efforts, and then only by chance was a colony of the parasite discovered on a plate containing some 200 others of which thirty had been already investigated and proved to be saprophytic organisms. In one investigation upon which he is at present engaged more than 400 cultures have already been made and many more will be necessary before the investigation is satisfactorily concluded. Again Smith and Townsend(44) worked most patiently for three years upon the "Crown Gall" disease before the causal organism was tracked to his lair. Another instance may be cited in emphasis of the difficulties encountered in this branch of pathology; Schiff-Giorgini(41) in investigating the Olive Knot disease worked for two years upon an organism thought to be $B$. Oleae which was later shown by Smith (13) to be a common soil organism and incapable of producing the disease. To quote from Smith (45), "The labor involved is enormous and exacting to discouragement at times, the results come so slowly, so much must be done to be certain of so little, all because the organisms dealt with are very small-how small, we seldom realise!"

The British literature on bacterial diseases is so scattered and so fragmentary that it seems advisable to collect together the fragments and to "take stock" of our position. An attempt is therefore made in this article to bring together the known facts about our bacterial diseases in the hope that it may be useful to those engaged in diagnostic work, and that it may in some measure stimulate the advancement of this important branch of phytopathology. 


\section{White Rot of Turnips and other Vegetables.}

This disease investigated by Prof. Potter in 1900 (36) was the first disease of bacterial origin to be recognised in this country. It is characterised by the complete rotting of the tissue attacked, the bacteria secreting an enzyme which has the power of dissolving away the middle lamella from between the cells thus destroying the coherence of the tissue and giving rise to the condition of a "Soft rot."

Symptoms of the disease. The first symptoms of disease appear in the autumn as a wilting and yellowing of the oldest leaves which droop to the ground, shrivel up and finally rot away. During a fortnight or three weeks the signs of disease progress inwards from the oldest to the youngest leaves until at the end of this period the plant has completely gone to the ground as a rotting, stinking mass. The root is found at this time to be partially or wholly reduced to a greyish white or brown pulpy mass.

The parasite. Potter was the first to isolate an organism in connection with this disease. He described a small uniflagellate rod under the name Pseudomonas destructans. Johnson and Adams (19) isolated an organism from rotted turnips in the West of Ireland which they believed to be Potter's organism, and also found it to be uniflagellate. They, however, draw attention to the close similarity of this to Bacillus Oleraceae isolated by Harrison (16). Jones (22) obtained a culture of a second isolation from Potter and found the organism to be a bacillus, and Harding and Morse (22) have shown that under similar cultural conditions both Harrison's oryanism and Potter's second isolation are identical with B. carotovoru: Jones. The writer obtained in 1912 a culture of $P$. destructans from Kral's laboratory and a slide stained by Loeffler's method showed flagella very indistinctly but each organism appeared to have a single flagellum. In 1916 it was restained by Steven's modification of Van Ermengen's stain and it was then clearly seen that the majority of the organisms were uniflagellate but that some, perhaps 10 per cent., were bacilli. That the number of flagella in bacteria is somewhat variable has been pointed out by Johnson and Adams(19) and the writer has found that $B$. atrosepticus grown on living turnips, and also sometimes on living potato, is present mainly in a uniflagellate condition. Potter has agreed (37) that his organism may have been a bacillus. Upon the evidence, therefore, it seems well to abolish the name $P$. destructans until a definitely uniflagellate organism answering exactly to the description given by Potter shall be again obtained from rotted turnips or other tissue. 
The causal organism is then $B$. carotovorus, a rod-shaped organism of varying length motile by $3-6$ peritrichous flagella. It stains well with the usual stains and is Gram negative'.

Host plants and distribution. The distribution of the disease seems to be general throughout Great Britain and Ireland and a great variety of hosts are liable to attack. B. carotovorus has been found by several investigators to be capable of producing rot in a great variety of plants, in the roots of carrot, white turnip, parsnip, rape, radish, salsify, in onion bulbs, hyacinth corms, cabbage, cauliflower, celery stalks and potato tubers. No rot has been produced in young carrots or parsnips, apple, pear, beetroot, sugar beet, swede turnips or tomato stems.

\section{Heart-rot of Celery.}

A soft rot of celery, in which sometimes the petioles of the outer leaves only, but in more serious cases the heart and subsequently the whole plant, are reduced to a yellowish brown decaying mass, was described by Wormald in 1914 (49) and an organism was isolated and named B. apiovorus. The disease had previously been observed in Ireland by Johnson and Adams in 1910 (19) who had isolated an organism but had not studied it fully. In a later paper Wormald (50) gives the results of a comparison of his organism with a strain of B.carotovorus, which we have had growing in this laboratory since 1912 when it was obtained from America through the courtesy of Dr E. F. Smith. As the result of this later work Wormald concludes that the two organisms are identical and that "Heart-rot" of celery is the work of that omnivorous organism $B$. carotovorus.

\section{"Blackleg" of the Potato.}

This is a disease which produces entire destruction of the plant when the attack occurs early in the season and a disastrous soft rot of the tubers during storage when, following a late attack in the field, a certain percentage of the tubers are so slightly affected at the time of lifting that their diseased condition goes unnoticed. The rot spreads from these diseased tubers to neighbouring healthy ones and the loss of the whole or a considerable part of the store frequently results.

1 In order to save space no attempt is made in this article to give the full description of the cultural and physiological characters of the various organisms dealt with. These are readily available in the literature and where a full description of an organism is given in any paper to which reference is made an asterisk has been placed against the reference in the list of literature cited.

Ann. Biol. v 
Symptoms of the disease. The first sign of disease is to be observed in the foliage. The leaves turn yellow or much paler green than healthy leaves and diseased plants can readily be recognised in the early stages by this character alone. At the same time they retain a rather erect position on the stem instead of spreading out horizontally and the edges exhibit a rolling towards the mid-rib. The rolling should not be confused with that of "Leaf-roll" since it is of cylindrical form rather than funnel shaped and there is entire absence of the pink or purple pigmentation characteristic of this disease. In the later stages of disease the leaves wilt and the whole plant assumes a brown to black colour and a very dejected appearance. The plants remain standing in the field in virtue of a special hardening of the three main vascular bundles of the stem. These quite early become browned for a considerable distance up the stem and are so hard that a sharp knife is needed to cut them transversely. The name "Blackleg" is derived from a characteristic blackening of the tissues of the stem commencing in the underground portion and extending to a height of two to three inches above the soil level. In the lower portion of the stem the pith is completely rotted away leaving a cavity in which fungal mycelium, easily recognised as that of saprophytic forms, is frequently present. The tissues in the upper portion of the stem appear sound except for the browning of the vascular bundles above mentioned and for a water-logged appearance of the pith for a centimetre or so above the upper limit of the cavity caused by the destruction of the pith cells of the lower portion. If the attack has occurred early in the season no tubers or only very small ones will have formed and anchorage in the soil is so slight that the least pull is sufficient to lift the plant. If, however, the plant is attacked after the tubers have well formed these will be infected by the organism through the vascular system of the underground stems. Such infected tubers will in warm moist weather rot off completely in the soil, but it more frequently happens that at the time of "lifting" the organism has not advanced from the vascular system and outwardly the tuber appears quite sound. These infected tubers give rise to the trouble in storage mentioned above and it is to them that the chief losses incurred through this disease are attributable. The organism may remain localised in the vascular ring of the tuber throughout the winter and the planting of diseased "sets" is believed to be the chief cause of dissemination of the disease.

The parasite. Several organisms have been described as giving rise to this disease but recent work by Morse (31) has shown that they are in all probability all strains of one species $B$. atrosepticus. Previously the name 
B. phytophthorus was most frequently employed and Johnson(18) states that he isolated this organism from diseased potatoes in Ireland in 1906. His evidence however has not been published, and the differences between B. phytophthorus and another strain B. melanogenes isolated in the West of Ireland by Pethybridge and Murphy (34) are so slight that it is conceivable that they were overlooked by Prof. Johnson. The B. melanogenes strain was isolated by the author(32) from potatoes grown in Lancashire and it is possible that it is the onjy one present in the British Isles ${ }^{1}$.

B. phytophthorus was not included in the strains examined and found to be identical by Morse but he had before him a culture of $B$. melanogenes and this under similar cultural treatment gave identical reactions with B. atrosepticus.

B. atrosepticus is a medium-sized bacillus with rounded ends motile by 3-6 peritrichous flagella and does not stain by Gram's method.

Distribution. This disease has been reported from all parts of the British Isles but the causal organism has been isolated only in the three instances mentioned above. It is a disease which seems to be definitely on the increase and unless some efficient means of control can be found may cause a great deal of trouble in the near future.

Host plants. Carruthers (9) isolated an organism from beans (Vicia $F a b a)$ which he believed to be identical with B.atrosepticus and the author has found that this organism is strongly parasitic towards Vicia Faba, and Appel(1) has shown that besides beans, carrots, turnips, cucumbers, tomatoes, sugar beet and mangolds are also liable to attack.

\section{Brown Rot of Potato and Tomato.}

A disease which has been very fully described by E. F. Smith (42) in which the vessels of potatoes and tomatoes become blocked with bacteria,

1 Johnson has stated (20) that he has isolated three other organisms from diseased potato plants in Ireland, namely, $B$. caulivorus, $B$. solanincola and Kramer's bacillus to which Migula gave the name $B$. solaniperda, no evidence in support of the identification is however produced. B. caulivorus has been considered by Laurent (24) to be identical with B. fluorescens liquefaciens the pathogenicity of which still remains rather doubtful and is being investigated at the present time in this laboratory; it was found that from a prick infection with $B$. atrosepticus of a bean stem without special precautions to sterilise the opidermis the resulting rot gave a pure culture of a fluorescent bacillus and it is possible that whenever $B$. fluorescens has been isolated from diseased plants its existence is a saprophytic one following initial attack by some other organism. The pathogenicity of B. solanincola has been called in question by Smith (42) and there is some doubt expressed by Appel (2) as to whether the experiments of Kramer (23) are sufficient to establish the pathogenicity of his bacillus also. 
an accompanying brown stain rendering the vascular bundles clearly discernible through the cortical tissue. The organisms enter the potato tuber through the stolon and produce there a brown stain in the vascular ring. From this the disease spreads as a brown rot into the storage tissue which is finally completely destroyed.

Massee (28) states that the disease has been recorded from several districts in the North of England and in Scotland. He gives a drawing which is strongly suggestive of Smith's disease and it is highly probable that the disease exists in this country, though in the absence of any evidence of the isolation of the causal organism it is still uncertain whether the English disease is etiologically identical with the American.

\section{IRIS Rot.}

The leaves become yellow, wilt and die. The underground portion of the plant becomes completely rotted. Massee (29) states that the disease is quite common in this country and the author has seen it in the beds at the Chelsea Physic Garden though the causal organism has not been isolated in this country. van Hall (15) found $B$. omnivorus and two species of Pseudomonas responsible for the disease on the continent.

\section{Yellow Disease of Hyacinth.}

Wakker's Disease of Hyacinth due to $P$. Hyacinthi and fully de scribed by Smith (42) occurs in our nurseries but, so far, not to any great extent. The organism was isolated by the writer from a diseased corm, recently imported from Holland, growing in one of our large nurseries in 1915 and was found to give all the characteristic reactions of $P$. Hyacinthi and to give rise to the characteristic symptoms of the disease in a corm of Roman Hyacinth (Hyacinthus orientalis) when the cut surface of this was smeared with a loopful of the organism from an agar slope.

\section{Black Rot of Cabbage and other Cruciferous Plants.}

The bacteria enter the leaf through the water pores causing a yellowing of the neighbouring tissue. They pass then to the veins, which become strongly blackened, and travel by way of the vascular bundles to the root which may become almost entirely hollowed out by the rot. The disease is also spread by slugs and this is probably the more usual method of infection. 
The symptoms of the disease and a very full account of it are given by Smith (42). The disease was observed in England in 1901 (30) and investigated by Potter(38) who isolated a Pseudomonas and in Ireland in 1910 by Johnson and Adams (19) who state that they isolated $P$. campestris though their published evidence is insufficient to establish this identity. Miss Doidge(13) has found P. campestris in diseased cabbages raised from English seed.

The parasite. P. campestris is a short rod-shaped organism with rounded ends, motile by means of a simple polar flagellum.

Host plants. Practically all members of the Cruciferae are attacked by this organism, cabbages, brussels-sprouts, turnips, swedes, radish, rape, etc.

\section{Bacterial Blight of Frutt Brossoms.}

The blighting of pear and other blossoms and the consequent loss of fruit has long been recognised as one of the worst evils with which the fruit grower is beset. This had almost universally been considered to be due to the effects of frost or of cold winds until the matter was investigated by Barker and Grove (3). That these agencies, especially the former, do cause a considerable amount of loss is indisputable, but probably the greater part of the blossom blight is due to bacterial infection. The bacterial origin of the disease was discovered in 1913 by Barker and Grove who succeeded in obtaining in pure culture from diseased blossoms an organism which readily reproduced the diseased condition when placed upon or injected into various parts of flower buds borne upon healthy young shoots.

Symptoms of the disease. The first symptoms of disease vary considerably in individual flowers according to the flower part first attacked. Infection may take place in the sepals before the opening of the flower bud. These first turn grey at the tips and soon commence to blacken downwards towards the flower stalk: subsequent infection of this rapidly leads to death of the whole bud. The same result is often to be observed if the petals receive the infection, but in this case it frequently happens that the attacked petals fall prematurely before the other flower parts have become involved and the young fruit may then set normally. The receptacle frequently bears the onset of the disease, and being an internal structure the diseased condition is liable to be overlooked, the resulting failure of the fruit to set being attributed to lack of fertilisation. Small greyish-black spots appear which in a short time spread over the whole receptacle and the disease is conveyed to the ovary. Finally, the disease 
may originate in the stigma, this becomes discoloured and the disease rapidly passes down the style to the ovary. Attacked blossoms showing very little obvious sign of disease may remain attached to the fruit spur for some considerable time and only fall when the tree is shaken by wind or otherwise, the slightest shaking being sufficient to bring down a shower of blossoms in all stages of development. After the fall of the flowers of a truss the spur may remain as a barren stump or may die back, this latter being in all probability due to subsequent attack by fungi such as Nectria ditissima or Sclerotinia fructigena since inoculation experiments with the causal organism on woody branches showed only slight damage. The organism may remain viable over the winter in the tissues of the spur left standing on the branch and thus may carry the disease over to the following spring.

The parasite. The causal organism is a medium sized rod with rounded ends motile by $2-5$ polar flagella with lophotrichous arrangement. It stains well with the usual stains and is Gram positive. The cultural and physiological have been investigated by the above named authors and amplified by Miss E. M. Doidge (12) who obtained a culture of their organism from Prof. Barker in order to make comparison of this organism with one isolated by her from diseased pear blossoms in South Africa. Miss Doidge found certain marked differences between the two organisms which seem to justify the founding of two separate species, but, in view of the work of Morse (31), which showed that quite as marked differences may disappear when two organisms are "trained" on the same media for some considerable time, it would seem desirable that treatment on the same lines should be applied to these two strains producing Blossom Blight before arriving at a definite separation. Miss Doidge's paper does not make it clear whether any previous training had been submitted to the two organisms before the parallel series of cultures was made.

Host plants. Barker and Grove found all the varieties of pear grown at the Long Ashton Research Station were susceptible to the disease, but that some were much more so than others; Beurre d'Amanlis and Catillac being specially susceptible. The bacillus has also been isolated from certain varieties of apples, plums and cherries. Barker(4) has also isolated an organism from gooseberry bushes which is believed to be identical with the organism causing pear blossom blight though no cultural evidence of this has as yet been given.

Distribution. The organism has been isolated from affected flowers from Gloucestershire, Devon, Middlesex, Sussex, Essex, Staffordshire and 
Herefordshire, and is probably wide-spread throughout the country although no statistics are available as to its occurrence in the North or in Ireland.

\section{Bacterial Blight of Tomatofs.}

Symptoms. When the tomato is quite small a minute blackish patch appears at the base of the style and from this focus the disease spreads until finally the whole fruit is reduced to a blackish soft decayed mass. It has been stated (27) that infection takes place during the flowering period and that needle prick infection from diseased tissue will set up disease in a healthy tomato.

In view of the fact that Brooks(8) holds that bacteria are not the primary cause of disease the matter badly needs further investigation in this country.

\section{Leaf Spot Disease of Orchid.}

Prof. Potter has described a bacterial blister on the leaves of Odontoglossim uro-skinneri(39), the epidermis being raised by an accumulation of brown mucilaginous substance caused by the action of some organism which is not fully described.

\section{Bacterial Diseasf of Pisum sativum.}

An interesting closed bacterial disease somewhat analogous to the closed smut of barley. The organism is present in the cotyledons of the seed, germinates with the seed, enters the plumule and passes up the stem of the plant in the motile stage and is to be found in the seed and the seed pod. It has been investigated by Miss D. M. Cayley (10) at the John Innes Horticultural Institution where for some years it has caused much trouble.

Symptoms of the disease. In the worst cases the badly infected seed fails to germinate, but usually the primary shoot develops from the infected seed, soon turns brown at the tip, aborts, and lateral shoots develop prematurely to take its place. Sometimes on the youngest shoots brown streaks are to be seen but otherwise there is no sign of disease until the flowering period. The disease develops most rapidly in hot dry weather, the stem becomes brownish and has a water-soaked appearance, brown longitudinal streaks appear on the stem at the base of the petioles, the leaves become spotted and yellowish with darkened veins and the surface of the pod is sometimes roughened or embossed. Fxcept in bad cases the plants grow to full height, flower and set a fair crop of seed but 
on examination of the seed the cotyledons are found to have brown spots or bacterial cavities at the centre of each:

The parasite. $P$. seminum is a large rod motile by a single polar flagellum. It stains well with the usual stains and is Gram positive. On solid media it readily forms oval bodies which may occur strung together in chains giving the appearance of beaded rods. These oval bodies are thought by Miss Cayley to be involution forms which contain certain particles, these stain as spores and are believed to be spores though their germination has not as yet been observed.

Host plants. At present the disease has been found only in Pisum sativum, all varieties of which would seem to be susceptible to more or less extent. The most susceptible varieties on the soil of the John Innes Institution being Ne Plus Ultra and Duke of Albany. The dwarf earlies Chelsea Gem and Little Marvel are also specially susceptible, while Sutton's Improved Petit Pois has proved on this soil to be least affected. In this variety, however, only about 50 per cent. of healthy plants were obtained.

Distribution. The disease is believed to be fairly common, at least throughout the South of England, and to be steadily on the increase. Miss Cayley reports that it is each year becoming more difficult to find seed for experimental purposes which can be relied upon to be free from this disease.

\section{Potato ScaB.}

The well-known corky patches or scabs on the skin of the potato are the result of the response of the cortical cells of the tuber to the stimulus of an invading organism and not, as has been frequently stated, the result of mechanical injury or of the attack of wire-worms or other animal parasites. In its defence against the parasite the tissue of the potato is so far successful as to limit the attack to a few of the outer layers of cells only. Successive layers of cork are formed as the organism penetrates into the tissue and these may extend to a depth of half a centimetre, but the internal storage cells remain unaffected. Bolley(6) isolated a small bacterium from scabbed potatoes in Indiana and with it produced scabs by artificial infection. Later however(7) he expressed doubt as to whether this organism is responsible for the disease under natural conditions, since, in subsequent efforts, he was unable to confirm his original work, but had no difficulty in showing that the usual cause of the disease is an organism which was isolated by Thaxter (48) and described as Oospora scabies. The disease was included amongst those 
of fungal origin until 1912 when Cunningham(11) showed the relation of Oospora scabies to the bacteria. In 1914 this organism was referred by Lutman and Cunningham(26) to Actinomyces chromogenus a species previously described by Gasperini(14).

Lutman and Cunningham have obtained four strains of Actinomyces chromogenus Gasperini from scabbed potatoes in America. Whether the cause of the disease is the same in this country is still uncertain, and the investigation of this matter is one of the many problems in plant bacteriology which call for elucidation. It is very unsatisfactory that a disease so long-established in the country should not yet have been attributed to a definite organism.

\section{Crown GaLL.}

An intumescence disease on the roots of various plants has been fully described by Smith and Townsend(44). The same symptoms of disease have been found on the roots of Paris daisy (25) (Chrysanthemum frutescens L.) grown at Kew; although the organism has not been isolated here there seems little reason to doubt that the disease is etiologically identical with that in America.

A very large number of host plants have been found to be affected with this disease. In this country they have been observed also in plum, rose, raspberry and loganberry and in the United States on peach, apricot, almond, prune, apple, cherry, poplar, chestnut and blackberry.

\section{So-Called Physiological Diseases.}

A number of obscure diseases have been attributed to a derangement of the normal physiological condition of the plant without the intervention of a parasite. This is in all probability a lame way of hiding our ignorance, and the possibility of the existence of ultra-microscopic organisms in these cases should always be kept in the fore-front.

The "Leaf-roll" disease of potatoes has been investigated thoroughly by Quanjer (40) who finds a pathological condition of the phloëm elements of the stem to which he ascribes the visible symptoms of disease. The facts that the disease is communicable to a scion by grafting a diseasebearing stock and vice versa and that it is transmissible through the soil would seem to point strongly to a bacterial origin of the disease, and further investigation is advisable before any cause other than a parasitic one is accepted for this disease. 
The "Mosaic Disease of Tomato" has also been shown to be transmissible through the soil and the same argument applies in this case also.

"Sprain" in potatoes is another of these obscure phenomena and there would seem to be several different kinds of "sprain." One form has been attributed (25), upon what evidence the author is unable to discover, to an arrested condition of Winter-Rot. Another form which has been described as "Internal Disease" by Horne(17) is believed to be similar to a disease which the writer is now investigating and which he has found to be due to a bacterial parasite (33).

"Silver-Leaf Disease" in plum has also been suggested as due to a bacterial parasite(5) and Smolâk ( +7 ) observed bacteria in the vessels of the leaf although the relationship of these to the disease was not determined.

The need for further investigation of bacterial diseases and for more workers in the field is vital, how vital has recently been shown by the discovery in America of two diseases of cereal crops, a bacterial blight of Barley (21) and a disease of Wheat (46); the latter is stated to be "not as destructive as the rusts but more destructive than the smuts and very likely more difficult to control." The means of control in bacterial disease are very difficult and necessitate a vast amount of research. Possible lines of attacking the problem have been so ably set out by Smith (45) in his Conspectus of Bacterial Diseases that little can be added in the present state of our knowledge.

\section{REFERENCES.}

An asterisk placed before a reference denotes that the culturat and physiological charasters of the organism deall with are described in the paper.

*(1) Apfer, O. Untersuchungen über die Swarzbeinigkeit und die durch Bakterien hervorgerufene Knollenfäule der Kartoffel. Arb. a. d. biol. Anst. f. Land-u. Forstwirthschaft am Kais. Gesundheitsamt. Bd. 11, 1903, s. 364.

(2) —- Arb. Kais. Btol. Anst. f. Land-u. Forstwirthschaft, Bd. v, 1905-7.

*(3) Barker, R. T. P. and Grove, O. A Bacterial Disease of Fruit Blossom. Ann. App. Bioi. vol. I, 1914, p. 85.

(4) Barker, R T. P. A Bacterial Disease of Gooseberry. Ann. Ryt. Agric. and Hort. Research Sta. Long Ashton, Bristol, 1915, p. 97.

(5) Blackmore, J. C. Annuai Repmi N. Z, Dep. of Agrie. 1909, p. 53.

(6) Bolley, H. L. Potato Scab: a bacterial Disease. Agr. Science, vol. Iv, 1890 , pp. $243,277$.

(7) - Potato Seab and possibilities of its prevention. N. Dakota Sta. Bull. 1891 .

(8) Brooks, C. Blossom end Rot of Tomatoes. Phytopull. vol. Iv, 1914, p. 345. 
(9) Carrutifers, W. Annual Rejzort. Journ. Roy. Agric, Sox. Eng. vol. Lxvil, 1907. p. 226.

*(10) Cayley, D. M. Bacterial Disease of Pisum satimum. Journ. Agric. Sci. vol. vill, 1917 , p. 461.

(11) Cunnengham, (i. C The relation of Oospora scabies to the higher bacteria. Phylopath. vol. It, 1912, p. 97.

*(12) Durdece, E. M. A Bacterial Blight of Pear Blossoms occurring in Soutli Africa. Ann. App. Biol. vol. rv, 1917, p. 50.

(13) -... S. Africun Journ. of Science, vol. XII, No. 10; note in Gardener's 'hromerle, vol. LXI, 1917, p. 11 .

(14) Gasperisi. Ricerche morp. et biol. sur genere Actinomyees. Ann. del lust. rr Igiene, Roma, vol. ir, 1891.

(15) van HaLl, C. J. J. Das Faulen der jungen Schosslinge und Rhizome von Iris florentina und Iris germanica verursacht dureh Bacillus omnivorus v. Hall und durch einige andere Bakterienarten. Zeitschr. f. Pflanzenkr. Bd. xirr, 1903, p. 129.

(16) Harrison, F. C. A Bacterial Disease of Cauliflower and Allied Plants. Centralbl. f. Balit. Aluth. II, Bd. xirr, J904.

(17) Horxf, A.S. The Symptoms of Internal Disease and Sprain (Streak Disease) in Potato. Joum. Agric. Sci, vol. 1I1, 1910, p. 322.

(18) Johnson, T. Some Injurious Fungi found in Ireland. Econ. Pros. Roy, Dublin Soc. vol. I, 18991900 , p. 345.

(19) _- - and Adams, T. Bacterial Rot in Turnipis and other Brassicas in Ireland. Eern. Proc. Roy. Dublin Sor, vol. 1I, 19i0, p. I.

(20) _- Diseases of the Potato and other Plants in Ireland. Jomrn. Dep. Agric. and T'ech. Inst. for Ireland, vol. Irı, 1902, p. 8.

(21) Jones, 1. R., Johnson, A. G. and Redny, C. S. Bacteriai Blight of Barley. Journ. Agric. Reseurch, vol. XI, 1917, p. 625.

*(22) Joyms, L. R., Harninf, H. A. and Morse, W. J. The Bacterial Soft-Rots of certain Vegetables. Neu: Yorh Agric. Exp. Sta. Tech. Bull. No. 11, 1909.

(23) Kramer, E. Bacteriologische Untersuchungen über die Nassfäule der Kartoffelknollen. Oesterreich. Landw. Centralbl. Bd. 1, 1891, s. 11.

(24) Lauren'c, E. Recherches expérimentales sur les Maladies des Plantes. Annales de l'Institul Pasteur, T. xIII, 1899, p. 38.

(25) Leaflets of the Board of Agriculture, Nos. 117, 137, 152, 200, 242 and 245.

*(26) Lutman, B. F. and Cunningham, G. C. Potato Scab (complete bibliography). Yermont E.xp. Sta. Bull. No. 184, 1914.

(27) Massee, G. Bacterial Disease of Tomatoes. Journ. Bd. of Agric. vol. XII, $1905-6$, p. 300.

(28) —- Some Potato Diseases. Journ. Bd. of Agric. vol. IX, 1902-3, p. 308.

(29) — Diseases of Cultivaled Plants and Trees, London, p. 513.

(30) Middeton, T. H. Black Dry Rot of Swedes. Joum. Bd. of Agric. vol. Ix, $1902-3$, p. 25.

*(31) Monse, W. J. Studies upon the Blackleg Disease of the Potato, with Special Reference to the Relationship of the Causal Organisms. Journ. Agric. Research, vol, viII, 1917, p. 79. 
*(32) Paixe, S. G. Studies in Bacteriogis. I. "Blackleg" of the Potato. Journ. Agric. Sci. vol. virI, 1917, p. 480.

(33) _- "Internal Rust Spot" Disease of the Potato Tuber. Ann. App. Biol.vol. v, 1918, p. 77.

*(34) Pethybridae, G. H. and Murphy, P. A. A Bacterial Disease of the Polato Plant in Ireland. Proc. Roy. Irish Acad. vol. xxIx, B, 1911, p. 1.

(35) Pottre, M. C. A Brief Review of Bacteriological Research in Phytopathology. Science Progress, vol. v, 1910-11, p. 191.

(36) - On a Bacterial Disease of the Turnip (Brassica napus). Proc. Roy. Soc. vol. Lxvit, 1901, p. 442.

(37) Poтrer, M. C. Bacterial Diseases of Plants. Journ. Agric. Sci. vol. Iv, 1911-12, p. 325.

(38) - Microscopic Investigations of Black Dry Rot in Swedes. Journ. Bd. of Agric. vol. Ix, 1902-3, p. 28.

(39) L- Leaf Spot of Odontoglossum uro.skinneri. Gard. Chron. vol. XLv, 1909, p. 145.

(40) Quanjer, H. M. On the Nature, Mode of Dissemination and Control of Phloëm-necrosis (Leaf-Roll) and related Discases (English translation). Mededeelingen van de Rijks Hoogere Land-, T'uinen Roschboutrschool, Deel x, p. 91.

(41) Schrff-Giongini, R. Ricerche sulla tubercolosi dell' ulivo. Reale Accademia dei Lincei (Anno cccl, 1904), Roma, 1905, p. 185.

(42) Sмттн, E. F. Bacteria in Relation to Plant Diseases. Carnegie Publication, Washington, D.C.

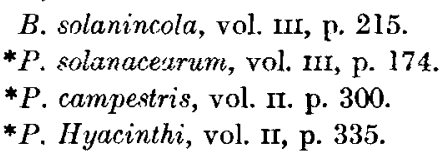

(43) - Recent studies of the olive tubercle organism. U. S. Dep. of Agric. B. P. I. Bull. No. 131, 1908.

(44) - and Townsend, C. O. A plant tumor of bacterial origin. Science, N. S. vol. $\mathrm{xxv}, 1907$, p. 671 .

(45) - A Conspectus of Bacterial Diseases of Plants. Ann. Missouri Bot, Gard. vol. II, 1915, p. 377.

(46) — A Nęw Disease of Wheat. Journ. Agrrc. Research, vol. x, 1917, p. 51.

(47) Sмоr.Âk. A Contribution to our Knowledge of Silver-Leaf Disease. $A n n . A p p$. Biol. vol. Ir, 1915, p. 138.

(48) Thaxter, R. The Potato Scab. Conn. (State) Sta. Rpts Nos. 14, 1891 and 15, 1892.

*(49) Wormald, H. A Bacterial Rot of Celery. Journ. Agric. Sci. vol. vi, 1914, p. 203.

(50) — The Celery Rot Bacillus. Journ. Agric. Sci. vol. virr, 1917, p. 216. 